\title{
The Role of MNE Subsidiaries in the Practice of Global Business Models in Transforming Economies
}

\section{Michael Zisuh Ngoasong, ${ }^{1} \odot$ Jinmin Wang, ${ }^{2} \odot$ Rolv Petter Amdam, ${ }^{3}$ and Ove Bjarnar ${ }^{4}$}

\author{
${ }^{1}$ The Open University Business School, UK, ${ }^{2}$ Nottingham University Business School, UK, ${ }^{3} B I$ \\ Norwegian Business School, Norway, and ${ }^{4}$ Molde University College - Specialized University in \\ Logistics, Norway
}

\begin{abstract}
ABSTRAGT This study provides new insights into the role of subsidiary managers in the practice of global business models of multinational enterprises in transforming economies. Drawing on the global business model literature and through semi-structured interviews with a leading Norwegian maritime multinational enterprise in China, we have developed and critically explored a theoretical framework for uncovering how subsidiary managers understand and manage the tensions between the headquarters based in a western country and the subsidiaries based in a transforming economy. More specifically, when implementing the global business model in the transforming economy, subsidiary managers need to undertake effective management of structural, behavioural, and cultural tensions along with the global integration-local responsiveness dilemma. Subsidiary managers can contribute to solving structural tensions between the headquarters and subsidiary by undertaking effective market sensing and knowledge transfer activities to integrate the transforming economies into the MNE's global production networks. Meanwhile, they need to make effective relationship management to solve behavioural and cultural tensions.
\end{abstract}

KEYWORDs China, global business models, global integration-local responsiveness dilemma, multinational enterprises, subsidiary managers, tensions, transforming economies

AGCEPTED BY Guest Editors Oli Mihalache and Henk Volberda

\section{INTRODUGTION}

International business scholars have intensified calls to critically examine business model innovation in transforming economies (Volberda, Van den Bosch, \& Heij, 2017). A global business model is a holistic concept that depicts how firms create

Corresponding author: Jinmin Wang (jinmin.wang@nottingham.ac.uk)

(C) The Author(s), 2021. Published by Cambridge University Press on behalf of The International Association for Chinese Management Research. This is an Open Access article, distributed under the terms of the Creative 
and capture value, achieving strategic fit across different types of business units, activities, or networks across borders (Aspara, Lamberg, Laukia, \& Tikkanen, 2013; Teece, 2010; Volberda et al., 2017). MNEs are facing many challenges in innovating and implementing their business models due to the complicated coordinating processes and effective resource deployment in an extended global setting. The implementation of a global business model by MNEs is closely related to the management of headquarters-subsidiary relationships (HQS) because global business models are established on interconnectivity and synchronization between headquarters and foreign subsidiaries (Tallman, Luo, \& Buckley, 2018).

Previous research has highlighted the strategic role of the subsidiary (Birkinshaw, Holm, Thilenius, \& Arvidsson, 2000), the management processes of MNEs (Chini, Ambos, \& Wehle, 2005), and the level of subsidiary autonomy and knowledge flows (Asakawa, 2001). However, there is still limited understanding of how subsidiary managers manage and overcome the tensions between headquarters and subsidiaries when implementing global business models in transforming economies. Subsidiary managers carry into the MNE's network perceptual and decision-making abilities to construct boundaries between headquarters and customers/partners in the transforming economy (Wei, Samiee, \& Lee, 2014). They contribute to translating, adapting, and acting on the MNE's global business model in contextually appropriate ways as well as enrolling actors in the global business network in ways that shape and make the markets (Lunnan \& McGaughey, 2019; Mason \& Spring, 2011). Thus, we address a key research question in this article: How do subsidiary managers of an MNE manage tensions between headquarters and subsidiaries when implementing the global business model in the transforming economy?

By addressing the above research question, this article makes two important theoretical contributions to the global business model literature. First, we have developed and critically explored a theoretical framework for uncovering how MNEs address the tensions that develop between headquarters and subsidiary managers in implementing global business models in transforming economies. We have extended the understanding of global business model implementation in the transforming economy to complement previous conceptual studies (Baden-Fuller \& Haefliger, 2013; Tallman et al., 2018) and empirical research that mainly focuses on developed nations (Dunford, Palmer, \& Benveniste, 2010; Khanagha, Volberda, \& Oshri, 2014).

Second, we have uncovered how the management of structural, behavioural, and cultural tensions by subsidiary managers enables MNEs to deal with the global integration-local responsiveness dilemma (Bartlett \& Ghoshal, 1998) more effectively when implementing global business models in the transforming economy. Tallman et al. (2018) suggest that the global business model thinking poses the question of how a firm operating in different countries can utilize just one global business model and the implications for integrating global competitive pressures into global business model thinking. Our findings demonstrate the usefulness of 
a global business model as a construct for analysing the practices used by subsidiary managers in implementing the MNE's global business model in a transforming economy.

Focusing on China as a transforming economy, we have not only extended the global business model literature by uncovering the tensions arising from the practice of global business model by subsidiary managers, but also looked into how these tensions can be overcome by MNEs. Our empirical evidence is based on a qualitative study of the subsidiaries of one leading Norwegian maritime MNE in China. China is a suitable transforming economy in this study because of the rapid development of the maritime industry and growing opportunities for MNEs. Its contrasting institutional profile, when compared with western countries (such as Norway), provides a relevant setting for examining challenges faced by MNEs (Couper, 2019). Our findings reveal that the implementation of MNEs' global business model in a transforming economy requires subsidiary managers to unpack a perceived rationally coherent global business model from the perspective of the headquarters.

The next section reviews the key literature used to analyse how subsidiary managers of MNEs manage the tensions and global integration-local responsiveness dilemma in implementing global business models, followed by the research methods. The empirical results, discussion of the findings, and conclusions are then presented.

\section{LITERATURE REVIEW}

\section{Global Business Models of MNEs}

This study analyses how subsidiary managers of MNEs in transforming economies manage tensions when implementing global business models developed in the MNEs' headquarters (HQS). A business model offers 'an analytical framework through which managers can seek to make sense of and share understanding between individuals, groups, and organisations of what the situation is in order to "work out" what is to be done' in the market in which they are operating (Mason \& Spring, 2011: 1038). This sense-making and sharing of understanding during implementation introduces a practice-orientation, in which the creation of a model is a pragmatic activity involving adjustments that are based on the objective(s) to be achieved rather than the literal suitability of such adjustments (Ngoasong, 2010). The practice of a global business model involves both the headquarters and subsidiary managers undertaking different kinds of corporate versus business unit activities to achieve strategic fit across the MNEs' global activities (Aspara et al., 2013; Luo \& Child, 2015). This subjectivity is drawn upon in our analysis to uncover the local responsiveness of MNEs' global business model through examining the practices of subsidiary managers in a transforming economy. 


\section{Tensions in Headquarters-Subsidiary Relationships of MNEs}

The dynamic change of HQS within MNEs has been attracting substantial research interest among international business scholars, for example, as seen in a recent review that identifies subsidiary roles and regional structures as critical to the success of MNEs' international activities (Kostova, Marano, \& Tallman, 2016). As summarised in Table 2, the key literature reveals the structure and strategies, means of coordination and integration, as well as the organisation costs through HQS management (e.g., Lunnan, Tomassen, Andersson, \& Benito, 2019). To achieve a balanced relationship, headquarters make decisions on the basis of an understanding of the cultural needs, organizational situations, and a shared organizational global vision, core values, and cultural principles by headquarters and subsidiary managers (Rodrigues, 1995). However, there are usually differences in the perceptions by headquarters (HQ) managers of western MNEs and their subsidiaries in a transforming economy, which can lead to poor relationships, conflicts, and ineffective relationships (Chan \& Holbert, 2001). Toth, Peters, Pressey, and Johnston (2018) discuss structural, emotional, and behavioural tensions that arise during the implementation of large projects as causes of conflicts and poor relationships within MNEs.

Thus, differences in perceptions and conflicts between HQ and subsidiaries as sources of tensions are relevant considerations for MNEs' local responsiveness when implementing global business models in host countries (Tallman et al., 2018). To understand and manage tensions, previous research has focused on subsidiary managers' knowledge mobilizations that initiate lateral and bottom-up exchanges from HQ to subsidiaries (Tippmann, Scott, \& Mangematin, 2014). This notion of knowledge flows is also related to the dynamic capabilities perspective on HQS in transforming economies. Fourné, Jansen, and Mom (2014) identify three dynamic capabilities, including market sensing local opportunities, enacting global complementarities, and appropriating local value, which can help MNEs manage and operate successfully across emerging and established markets. However, it is important to address the tensions among these capabilities effectively. Managing tensions in a transforming economy also includes resolving HQ-subsidiary conflicts through increased communication, greater trust in the mutual capabilities, and deeper collaboration in confronting common challenges (Tasoluk, Yaprak, \& Calantone, 2006).

\section{Role of Subsidiary Manager in the Practice of Global Business Models}

The preceding review suggests that unpacking the role of subsidiary managers in the challenging HQS involves identifying a mixed-motive dyad, where interests and perceptions may not be completely aligned (Birkinshaw et al., 2000; Luo, 2003). MNEs encompass both an internal environment and an external environment, which consist of customers, suppliers, competitors, and other stakeholders in both domestic and international markets (Andersson, Forsgren, \& Holm, 
Table 1. Summary of key global business model literature

\begin{tabular}{|c|c|c|}
\hline Authors (Year) & Study type & Key content \\
\hline $\begin{array}{l}\text { Aspara, Lamberg, } \\
\text { Laukia, \& } \\
\text { Tikkanen, } 2013\end{array}$ & $\begin{array}{l}\text { Historical / } \\
\text { archival study }\end{array}$ & $\begin{array}{l}\text { Identify/discuss the cognitive drivers of existing corpora } \\
\text { business model elements that top managers decide to } \\
\text { retain and/or renew in complex business settings }\end{array}$ \\
\hline $\begin{array}{l}\text { Baden-Fuller \& } \\
\text { Haefliger, } 2013\end{array}$ & Conceptual & $\begin{array}{l}\text { Business model as a system that solves the problem of } \\
\text { identifying the customer(s), engaging with their needs, } \\
\text { delivering satisfaction, and monetizing the value. }\end{array}$ \\
\hline
\end{tabular}

\section{Dunford, Palmer, \& Empirical}

Benveniste, $2010 \quad$ (Qualitative) identifying the customer(s), engaging with their needs,

The processes through which business model replication can provide a basis for the early and rapid internationalisation of $\mathrm{MNE}$ in foreign markets

Multi-actor service infusion and diffusion process through the reconfiguration of a business model over a period of time
Theoretical findings

Business models as binary choices to be synthesised by corporate and unit-level managers to understand and work with paradoxical tensions. Future research should identify opportunities in the environment, the behaviour of managers, or the initiatives of other stakeholders than top managers (or investors), internal and external to the firm. Business model as a set of cognitive configurations with fourpart typology: customer sensing, customer engagement, monetization, and value chain, and linkages. Business models contain theory and assumptions about customer behaviour and agency that may not hold in a specific situation (and how this can guide managerial action).

Four processes (clarification, localization, experimentation, and co-option) determine the business model evolution

during an MNE's early and rapid international expansion. Uncovers the processes and nature of inter-subsidiary and head office-subsidiary interaction in the context of early and rapid internationalisation through global business model implementation.

Develops and elaborates on a process theory for understanding the business model characteristics and the knowledge conversion mechanisms and the associated capacities involved for each of the phases underlying the reconfiguration of the focal firm's business model. 
Table 1. Continued

$\begin{array}{llll}\text { Authors (Year) Study type } & \text { Key content } & \text { Theoretical findings }\end{array}$

Mason \& Spring, 2011 Historical / The multiple and changing sites of business models and the archival study various combinations of practices through which this happens.

Develops a framework in which technology, market offering, and network architecture are three interlinked components for analysing how managers develop, represent, translate and transform business models within and between organisations, industries, and across multiple geographies

Tallman, Luo, \& Conceptual How do MNEs relate the choice of business model to their Buckley, 2018 strategic context?

Global business models consist of value proposition, value creation, value delivery, value capture, and value allocation activities of MNEs. Future research should apply business model thinking to uncover how MNEs deal with global integration-local responsiveness dilemma.

Teece, $2010 \quad$ Conceptual How are business models, business strategy, and innovation interlinked?

thess model is a source of competitive advantage where the design or architecture of the value creation, delivery, and capture mechanisms of the firm enables the delivery of customers' needs and be non-imitable. 
Table 2. Summary of key literature regarding tensions in headquarters-subsidiary relationships

\begin{tabular}{llll}
\hline Authors (Year) & Study type & Relevance & Major findings
\end{tabular}

Major findings

Chan \& Holbert, $2001 \quad \begin{gathered}\text { Empirical } \\ \text { (Qualitative) }\end{gathered}$

Differences in the perceptions of

Fourné, Jansen,

Empirical
the marketing process between the headquarters and subsidiaries

\& Mom, 2014

(Qualitative)

Lunnan, Tomassen,

Empirical

Andersson, \& Benito, 2019 (Quantitative)

Manage tensions to capture opportunities across emerging and established markets

Finds that important divergence between home and away in various aspects of the marketing process of MNCs exists, which may lead to poor relationships, dysfunctional conflict, and ineffectiveness.

Identifies and illustrates three dynamic capabilities (sensing local opportunities, tom global complementarities, and appropriating local value) by which MNEs are able to operate successfully across emerging and established markets. Doing so demands embracing the tensions between these capabilities effectively. Interactions between subsidiaries and headquarters in terms of organizing costs

Patriotta, Castellano, \& Empirical

Wright, 2013

(Qualitative)

Global managers as higher-level intermediaries for knowledge search and knowledge transfer in different contexts

Rodrigues, 1995

Conceptual

Headquarters-foreign subsidiary control

relationships

Tasoluk, Yaprak, \&

Empirical

Calantone, 2006

(Qualitative)
Finds that relationship atmosphere significantly reduces both information and and formalization reduce information costs, whereas social integration increases bargaining costs.

Argues that global managers, as higher-level intermediaries, act as 'ambidextrous ties' able to connect formal and informal knowledge search and transfer mechanisms across functional and geographical boundaries of MNCs.

Suggests that it is important for MNEs to establish a balanced HQS relationship. It can be achieved when managers at the headquarters make decisions on the basis of an understanding of the cultural needs of foreign subsidiary managers, the specific organizational situations, and a shared organizational global vision, core values, and cultural principles by all subsidiary managers.

Recommends the mechanisms for resolving conflict through increased communication, greater trust in each other's capabilities, and greater collaboration in meeting common challenges. bargaining costs, whereas distance increases bargaining costs. Centralization
The collaborative intent, trust development, and conflict resolution in a headquarters-subsidiary relationship in a new product launch context in an emerging market. 
Table 2. Continued

\begin{tabular}{llll}
\hline \hline Authors (Year) & Study type & Relevance & Major findings \\
\hline $\begin{array}{l}\text { Tippmann, Scott, \& } \\
\text { Mangematin, 2014 }\end{array}$ & $\begin{array}{c}\text { Empirical } \\
\text { (Qualitative) }\end{array}$ & $\begin{array}{c}\text { Subsidiary managers' knowledge } \\
\text { mobilizations }\end{array}$ & $\begin{array}{c}\text { Subsidiary managers use knowledge mobilization to initiate a complex pattern of } \\
\text { subsidiary knowledge inflows, pinpointing the significance of lateral and } \\
\text { bottom-up exchanges (locally as well as internationally). }\end{array}$ \\
$\begin{array}{c}\text { Toth, Peters, Pressey, \& } \\
\text { Johnston, 2018 }\end{array}$ & $\begin{array}{c}\text { Empirical } \\
\text { (Qualitative) }\end{array}$ & $\begin{array}{c}\text { Analyse tensions arising in complex } \\
\text { industrial networks }\end{array}$ \\
\hline \hline
\end{tabular}

= 
2007; Birkinshaw, Hood, \& Young, 2005). The role of subsidiary managers across host countries depends on the type of international strategy, the degree of headquarters' control, and subsidiaries' autonomy that vary across MNEs (Ambos, Andersson, \& Birkinshaw, 2010). Depending on their respective positions, subsidiaries usually possess deeper and more fine-grained knowledge about local markets in the host countries than headquarters because of their closeness to relevant market actors and institutions (Asmussen, Foss, \& Pedersen, 2013). This suggests that a headquarters-subsidiary perception gap may develop over time due to differences in the perception of challenges arising from different contexts. Linking this discussion about the role of subsidiary managers to the preceding review on the practice of global business models reveals two key steps for how global business models of MNEs can be appropriately adopted and implemented by subsidiary managers in transforming economies.

First, the role of subsidiaries in the practice of global business models can be uncovered in the decision-making processes that define HQS and how subsidiary managers clarify and adapt the core principles of global business models to achieve local responsiveness (Dunford et al., 2010). This is related to the global business model as both a cognitive and a linguistic schema. A business model can serve as 'cognitive structures that consist of concepts and relations among them that organize managerial understanding about the design of activities and exchanges that reflect the critical interdependencies and value creation relations in their firms' exchange networks' (Martins, Rindova, \& Greenbaum, 2015: 105). However, over focusing on business models as schema can lead to inertia, as schemas tend to be self-reinforcing, guiding managers to ignore relevant discrepant information and data gaps in favour of more familiar or readily available information (Massa, Tucci, \& Afuah, 2017). This inertia can be addressed by considering the cognitive dimension (collective and individual) and the linguistic one (communicating within the organization), for example, through analysing the communicative interactions between stakeholders when implementing the global business model (Wallnöfer \& Hacklin, 2013).

Second, subsidiary managers need to understand and interpret the component parts of the MNE's global business model and the challenges in transforming economies. The changes undertaken by subsidiary managers to suit a specific host country context and the subjective discretions in which they interpret and make judgements may end up determining the final outcome of implementation processes (Hambrick, 2007). In the context of the global business model, the outcome of decision-making processes includes adaptations to existing global business model principles, changes to the approach used to articulate key business model elements to respond to business opportunities, and/or deal with challenges in transforming economies. Here the role of subsidiary managers includes sensing and seizing local market opportunities (Fourné et al., 2014; Teece, Pisano, \& Shuen, 1997), creating and managing customer and supplier interactions systematically to improve market offerings, attract new customers, and respond to regulatory constraints in transforming economies (Dunford et al., 2010; Miozzo \&

(C) The Author(s), 2021. Published by Cambridge University Press on behalf of The International Association for Chinese Management Research 
Yamin, 2012). As higher-level intermediaries, headquarters, and subsidiary managers provide coordination across functional and geographical boundaries (Patriotta, Castellano, \& Wright, 2013) by making knowledge sources available, connecting the parties to the transfer, and generating opportunities for knowledge exchange (Forkmann, Ramos, Henneberg, \& Naudé, 2017). However, there is little understanding of how this occurs during the implementation of global business models by MNEs.

The development, innovation, and implementation of global business models by MNEs require cross-border coordination and cooperation between headquarters and subsidiaries. It is inevitable that tensions will arise from time to time. However, there has been limited research on how MNEs deal with such tensions in the course of implementing global business models in the transforming economies with special focus on the role of subsidiary managers. This article extends the global integration-local responsiveness framework (Bartlett \& Ghoshal, 1989) by not only theorising the tensions that MNEs face when implementing global business models in transforming economies (Fourné et al., 2014; Toth et al., 2018) but also showing how they are managed by subsidiary managers.

\section{METHODS}

\section{Research Setting and Sampling}

With the advent of falling global market shares and increased competition from low-cost shipbuilding and manufacturing firms in Asia and Latin America in the late 1970s, Norwegian maritime MNEs have responded by undertaking global business model innovation, switching from the development of customized vessels in Norway to the manufacturing of more standardized vessels by cooperating with external shipyards in transforming economies such as China (Amdam, Bjarnar, \& Wang, 2018). China is an appropriate transforming economy for this study because there are regulatory and cultural challenges for MNEs doing business in the country, in addition to developing one of the fastest-growing maritime industries in the world (Jia, You, \& Du, 2012; Kynge, Campbell, Kazmin, \& Bokhari, 2017). Such a local context can be a trigger for the innovative practices of the global business model by the subsidiaries of MNEs.

We purposively selected one leading Norwegian maritime MNE, which has a high presence in China, for this study due to ease of access (Plakoyiannaki, Wei, \& Prashantham, 2019). The MNE entered the Chinese market in 2001 with an initial plan to establish a joint venture with a Chinese shipyard to build vessels based on its own designs. In 2005, it had similar observations in Singapore, Brazil, and several European countries. However, the business plan for China was not put into practice before any substantial investment was made. Afterwards, the headquarters of the MNE in Norway changed its overall international strategy from owning its own 
shipyards in the transforming economies to cooperating with local strategic partners. Its business activities in China are currently being carried out by its three wholly-owned subsidiaries engaged in marketing and after-sale services, maritime engineering, maritime equipment manufacturing, and shipbuilding with local strategic partners during the time period for our research.

\section{Data Gollection}

The aim of the data collection process was to create rich accounts of subsidiary managers' experience and knowledge on the practice of the MNE's global business model in the transforming economy, hence focusing on firm-specific documents and key informant interviews (Eisenhardt \& Graebner, 2007). The documents mainly included annual reports and press releases published on the corporate website as well as the external news articles on the Norwegian maritime MNE's operation in the transforming economies in the trustworthy financial media such as Financial Times from 2011-2019.

Evidence arising from an in-depth case study can contribute to theory elaboration (Eisenhardt \& Graebner, 2007) and provide new insights into the practices of the MNE's global business model in the transforming economy. We focused on senior managers at both headquarters and subsidiaries as key decision-makers with persuasive powers in ensuring the international success of the MNE's global business model in the transforming economy (Zhang, Dolan, Lingham, \& Altman, 2009). We conducted thirteen in-depth, tape-recorded interviews at the MNE's subsidiary offices in China and headquarters in Norway during 2011-2013, each lasting about one or two hours (Table 3). The sample is such that senior executives ensure that the context of the MNE's global business model at both the headquarters and subsidiaries are incorporated in the analysis (Dunford et al., 2010) in a transparent manner (Aguinis \& Solarino, 2019).

Informed by the themes developed in our literature review, the interview guide had two parts. In the first part, we focused on the strategic objective, structure, and operations of the global business model, including identifying the role of the subsidiary. In the second part, we drew on the responses from the first part to ask questions about the tensions and perception gaps between the managers at the headquarters and subsidiaries during the implementation of the global business model. The semi-structured format of the questions gave informants additional freedom to direct the interviews towards the themes that were of specific significance to the tensions in the course of implementing the global business model in China by drawing on their experiences. The interviews in China were organized and conducted by the Chinese author and the two Norwegian authors. The two Norwegian authors conducted the interviews in the headquarters of the MNE in Norway. The differences in any issues that arose were discussed and resolved among the research team to ensure reliable and relevant data analysis (Mihalache \& Mihalache, 2020).

(C) The Author(s), 2021. Published by Cambridge University Press on behalf of The International Association for Chinese Management Research 
Table 3. Information on the interviews conducted

\begin{tabular}{|c|c|c|c|c|}
\hline $\mathcal{N}_{0}$ & Interviewee & $\begin{array}{l}\text { Date } \\
(d d / m m / y y y y)\end{array}$ & Venue & $\begin{array}{l}\text { Length } \\
\text { (hours) }\end{array}$ \\
\hline IV1 & CEO (Norwegian) & $02 / 09 / 2013$ & $\begin{array}{l}\text { Headquarters in } \\
\text { Norway }\end{array}$ & 2.0 \\
\hline IV2 & $\begin{array}{l}\text { Chairman of the Board } \\
\text { (Norwegian) }\end{array}$ & $02 / 09 / 2013$ & $\begin{array}{l}\text { Headquarters in } \\
\text { Norway }\end{array}$ & 2.0 \\
\hline IV3 & Manager in Design (Norwegian) & $17 / 04 / 2012$ & $\begin{array}{l}\text { Headquarters in } \\
\text { Norway }\end{array}$ & 2.0 \\
\hline IV4 & $\begin{array}{l}\text { Manager in Human resource } \\
\text { management (Norwegian) }\end{array}$ & $07 / 05 / 2012$ & $\begin{array}{l}\text { Headquarters in } \\
\text { Norway }\end{array}$ & 2.0 \\
\hline IV5 & $\begin{array}{l}\text { Manager in Marketing } \\
\text { (Norwegian) }\end{array}$ & $07 / 05 / 2012$ & $\begin{array}{l}\text { Headquarters in } \\
\text { Norway }\end{array}$ & 2.0 \\
\hline IV6 & $\begin{array}{l}\text { Senior Manager in Human } \\
\text { resources management } \\
\text { (Norwegian) }\end{array}$ & $\begin{array}{l}07 / 05 / 2012 \\
14 / 06 / 2012\end{array}$ & $\begin{array}{l}\text { Headquarters in } \\
\text { Norway }\end{array}$ & $\begin{array}{l}2.0 \\
1.0\end{array}$ \\
\hline IV7 & $\begin{array}{l}\text { General Manager in China } \\
\text { (Norwegian) }\end{array}$ & $\begin{array}{l}02 / 09 / 2013 \\
12 / 03 / 2013\end{array}$ & $\begin{array}{l}\text { Headquarters in } \\
\text { Norway } \\
\text { Subsidiary in } \\
\text { Shanghai City, China }\end{array}$ & $\begin{array}{l}1.0 \\
1.0\end{array}$ \\
\hline IV8 & $\begin{array}{l}\text { Manager of Production Unit } \\
\text { (Norwegian) }\end{array}$ & $06 / 04 / 2011$ & $\begin{array}{l}\text { Subsidiary in Ningbo } \\
\text { City, China }\end{array}$ & 2.0 \\
\hline IV9 & $\begin{array}{l}\text { Manager of Sales and } \\
\text { Engineering Unit (Chinese) }\end{array}$ & 08/04/2011 & $\begin{array}{l}\text { Subsidiary in Shanghai } \\
\text { City, China }\end{array}$ & 2.0 \\
\hline IV 10 & Director of Marketing (Chinese) & 08/04/2011 & $\begin{array}{l}\text { Subsidiary in Shanghai } \\
\text { City, China }\end{array}$ & 2.0 \\
\hline IV11 & Director of Engineering (Chinese) & 08/04/2011 & $\begin{array}{l}\text { Subsidiary in Shanghai } \\
\text { City, China }\end{array}$ & 1.0 \\
\hline IV12 & $\begin{array}{l}\text { Assistant to Director of Marketing } \\
\text { (Chinese) }\end{array}$ & 08/04/2011 & $\begin{array}{l}\text { Subsidiary in Shanghai } \\
\text { City, China }\end{array}$ & 1.0 \\
\hline IV13 & $\begin{array}{l}\text { Assistant to Director of } \\
\text { Engineering (Chinese) }\end{array}$ & 08/04/2011 & $\begin{array}{l}\text { Subsidiary in Shanghai } \\
\text { City, China }\end{array}$ & 1.0 \\
\hline
\end{tabular}

\section{Data Analysis}

Given that this article aims at theory development rather than theory elaboration, this study adopts the Gioia data analysis technique (Gehman et al., 2018; Gioia, Corley, \& Hamilton, 2013). This method can be effectively used to analyse small samples because, instead of focusing on comparing a certain number of cases, it centres on eliciting a data structure composed of first-order, secondorder, and aggregate dimensions based on theoretical sampling to stimulate theoretical insights (Gioia et al., 2013). Then the transcribed data is ordered according to hierarchical categories representing informant terms, followed by themes, and subsequently aggregate theoretical dimensions (Aguinis \& Solarino, 2019). Figure 1 provides a summary of our data structure.

The first phase consisted of identifying the first-order categories based on descriptive labels for the activities that interviewees reported and which we conceptualized during our analytical procedure as narratives about the global integration- 
local responsiveness dilemma, structural, behavioural, and cultural tensions in the practice of global business model by the subsidiaries of Norwegian maritime MNE in China. Through the documentary analysis and interview data, we identified the major component parts of the global business model of the Norwegian maritime MNE, from the perspectives of both the HQ and the Subsidiary in a transforming economy (China).

The second phase consisted of an iterative process to identify the constructs that were more abstract. Congruent with our literature review, analysis of the first-order categories revealed the component parts of global business models in the interpretations of interviews, which triggered the judgement of subsidiary managers when implementing the global business models in the transforming economy. The third phase consisted of identifying key theoretical dimensions emerging from the second-order constructs. For this, we undertook the analysis of the communicative interactions (Wallnöfer \& Hacklin, 2013) between the MNE headquarters and subsidiaries before aggregating to reveal the practices of MNE subsidiaries with respect to working with and managing the tensions with the headquarters in the process of implementing the MNE's global business model to ensure local responsiveness in the Chinese market. Finally, from the data structure (Figure 1), we condensed the relationships between the key concepts into an emergent theoretical framework (Aguinis \& Solarino, 2019; Gioia et al., 2013). Our findings are presented below.

\section{RESULTS}

\section{Global Integration-Local Responsiveness Dilemma}

For the Norwegian maritime MNE we interviewed, unpacking the inter-linked component parts of its global business model and the communicative interactions

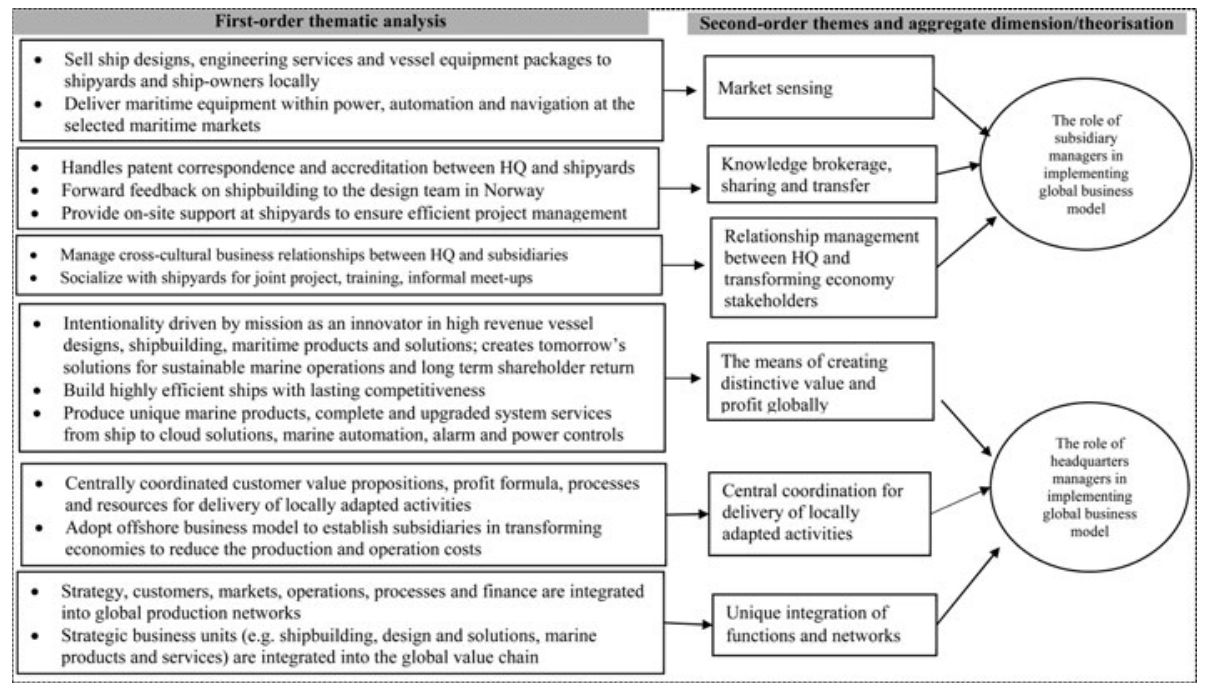

Figure 1a. Data structure

(C) The Author(s), 2021. Published by Cambridge University Press on behalf of The International Association for Chinese Management Research 


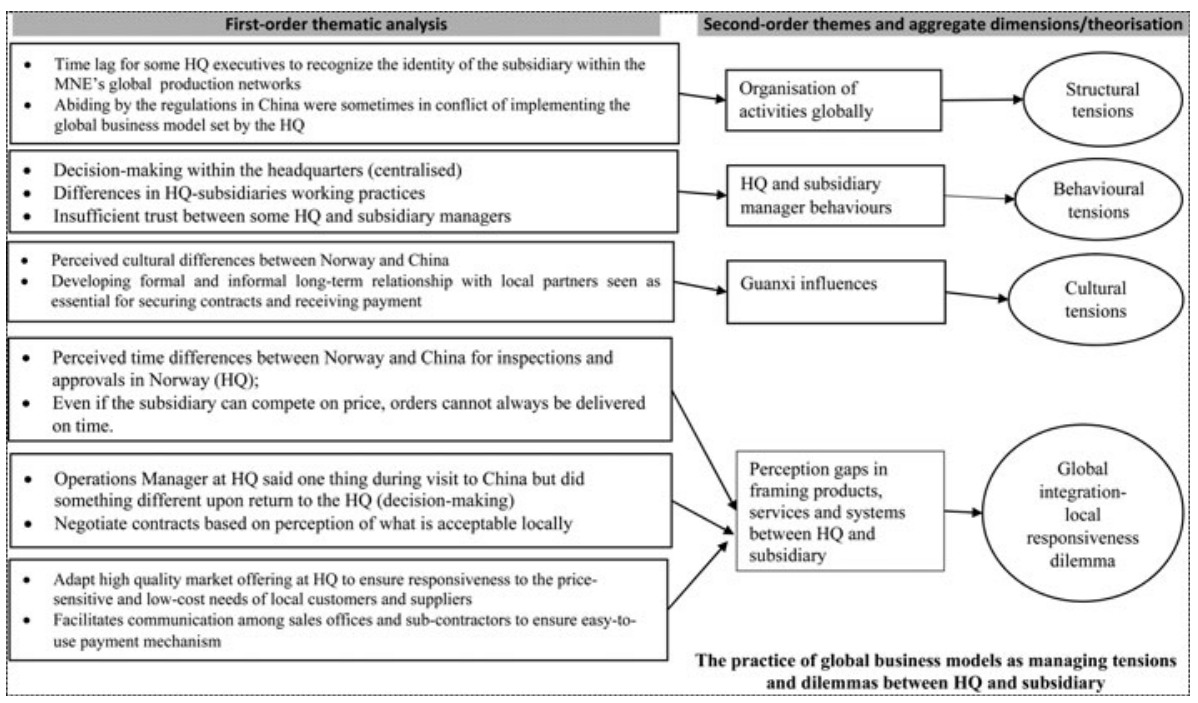

Figure 1b. (Continued)

between the headquarters and subsidiary managers revealed the complexities that come into play during the implementation process (Figure 1). The value propositions emphasise the product-service offerings. A fully integrated global business model enables the MNE to protect its product-service offerings because the configuration ensures that each business partner can contribute to the value creation through its global production networks, including shipyards, ship owners.

By expanding into transforming economies in Europe, Asia, and Latin America, the Norwegian maritime MNE is able to build more standardized vessels at a lower cost by using external shipyards than at its home shipbuilding base in Norway, thereby ensuring that the subsidiaries contribute positively to the MNE's value creation (Amdam \& Bjarnar, 2015). To establish a local presence while maintaining global integration, the subsidiary implements the MNE's global business model by acting as an agent and knowledge broker to facilitate the value creation, delivery, and capture in the transforming economy. This includes negotiating contracts that are signed between the headquarters in Norway and shipyards (value creation), manufacturing and supply of maritime equipment (design and technology), sales of maritime know-how and solutions (value delivery), and ensuring lower production and operation costs (value capture) in China. The CEO at the headquarters in Norway captured this vividly as follows:

What we do in China follows our international strategy of using partner yards, and we coordinate what we should do in Norway, Brazil, China, and other places. We have people on-site who control that these things are done.

However, when entering transforming economies in Europe, Asia, and Latin America, the Norwegian maritime MNE faces the global integration and local responsiveness dilemma like other western MNEs (Bartlett \& Ghoshal, 1998). 
Our data revealed a typical dilemma where the Norwegian maritime MNE's value creation focuses on high revenue designs and highly-efficient vessels that can be more expensive when compared with those produced in the transforming economies. The Director of Engineering in China commented as follows:

... Then they don't have the connection to the market. Some of the products in Norway is top of the art, state of the art products, but it has been engineered or produced by our engineer and the engineers like technical features. I feel that the link between the developer product and the market has been gone.

The above quote reveals that it is important for the headquarters in Norway to consider some adaptation of state-of-the-art products to meet the local needs of transforming the economy under the global business model due to contextual factors. Perception gaps can constantly arise between the headquarters in a western economy and the subsidiaries in a transforming economy. Therefore, the headquarters needs to keep in close touch and communication with their subsidiaries in the transforming economy because the subsidiary managers can keep sensing the local market and contribute to seizing on local business opportunities (Dunford et al., 2010; Teece, 2010). In addition to dealing with the global integration-local responsiveness dilemma, our data shows that subsidiary managers should manage structural, behavioural, and cultural tensions between the headquarters and subsidiaries effectively to ensure the successful implementation of the MNE's global business model.

\section{Structural Tensions}

Structural tensions arise from the organization of global business activities and global network governance between the headquarters and subsidiaries of MNEs (Fourné et al., 2014; Toth et al., 2018). In order to reduce production costs and improve integrated product-service offerings to clients, the Norwegian maritime MNE set up a second subsidiary in Ningbo City, East China in 2007, and appointed a Norwegian subsidiary manager in May 2008. This is related to value creation and the need to sustain value capture over the long term (Tallman et al., 2018). The subsidiary manager had rich work experience as a highly-skilled engineer for different multinational maritime firms in Norway. There were about 40 employees in the subsidiary in 2011, which mainly produced maritime electrical equipment for the headquarters in Norway, accounting for about $70 \%$ of its total output. Meanwhile, the subsidiary was also responsible for making procurement of maritime components from local companies in China for the headquarters.

Structural tensions emerged when a subsidiary manager found that it took some time for the headquarters to recognize the identity of his subsidiary within the global production networks of the MNE. He even supposed that one of the main reasons why the headquarters had ignored the subsidiary was because the

(C) The Author(s), 2021. Published by Cambridge University Press on behalf of The International Association for Chinese Management Research 
Chinese subsidiary did not have a competitive position within the MNE's global production networks. From an HQ manager's perspective, a competitive position is important for realizing value creation, and setting up a production unit linked to the MNE's global production networks (Lunnan \& McGaughey, 2019) facilitates the value that can be captured (Mason \& Spring, 2011). The subsidiary manager of the production unit in Ningbo City, China, made the following comment in the interview:

Didn't have the support, it was not planned, it was not..., most people didn't know about this factory the first year. How can they use this factory, how can they know how to use this factory if they don't know it's here?

As the business grew, the subsidiary manager and his colleagues gradually developed their knowledge about the local market and established more business relationships with local clients in China. This is related to the knowledge search and transfer role of subsidiary managers (Tippmann et al., 2014) in the sense that they initiate additional lateral and bottom-up exchanges, locally with Chinese partners and internationally with HQ managers. The new interactions also facilitated their market sensing role in that continual interactions increasingly urged them to explore new business opportunities in the transforming economy, which did not directly align with the global business model of MNE. This resulted in structural tensions between the subsidiary and the headquarters, as indicated by the subsidiary manager of the production unit in Ningbo City, China:

I hope so because then we remove one link, and if we cannot sell the design to a shipyard or ship owner, maybe they want to buy a Rolls Royce design, or maybe other local design on the vessel; then we can supply the power package to them directly. Now, we cannot do that. That's decided by the board of this company. This is where I'm trying to use my politics now!

Regarding the seizing of local business opportunities, the subsidiary manager of the sales and engineering unit in China stated clearly in the interview that he would like to challenge the global business model that the headquarters was implementing. He showed his intention to target new ship owners directly:

It will on the global but we are also targeting foreign ship owners that build vessels here in China because then we can have a different approach, instead of going directly to the shipyard, we can persuade the ship owner, we can tell them that 'you have to tell the shipyard that you want only this product from (the name of $M \mathcal{N} E$ ), you don't want anything else because of the quality of something.' Then, they can tell the shipyard 'we want the product from them'. Then we can deal with the shipyard directly.

The above quotation is related to perception gaps in the sense that whereas a headquarters' perspective might suggest a rational decision-making process for negotiating a contract (Lunnan et al., 2019), the subsidiary manager adopts a pragmatic approach in negotiating a contract based on its perception of what is acceptable within the local business environment. The contradiction between rational and 
pragmatic decision-making is related to structural tensions, which are organizational in nature (Fourné et al., 2014).

We also find that subsidiary managers must abide by local regulations in China, which were sometimes in conflict with implementing the MNE's global business model set by the headquarters. The interview data reveal an additional consideration, namely the time it takes to complete transactions given the institutional complexities in the transforming economy. This is captured in the following quotation by the Norwegian general manager in China:

In Norway, they can have, they can do a DNV [ a classification company] inspection on a switchboard after two to three days. You deliver the drawings for approval, the DNV, and then after two to three days, they can be at the factory and delivery inspection. Here in China, they do the approval in Shanghai. They told us they need 40 days! We have a disadvantage. For some orders, even if we can compete on price, it doesn't matter because we cannot deliver on time.

The above empirical analysis indicates that subsidiary managers need to deal with structural tensions when implementing global business models in transforming economies. However, their roles in sensing local business opportunities contribute to resolving the structural tensions by integrating the subsidiaries' local responsiveness requirements in the transforming economy into the MNE's global production networks, despite facing institutional complexities.

\section{Behavioural Tensions}

Behavioural tensions occur within MNEs when decisions are mainly made by the managers at the headquarters. We see this in the implementation of the global business model by the MNE in the transforming economy (Figure 1). Though it has a global focus without considering country-specific factors fully in the transforming economy, the framing of the component parts allows the subsidiary managers to be able to interpret and judge what adaptations might be needed in a specific transforming economy. This was typified by the Norwegian maritime MNE in the study, where its subsidiary had not been fully informed of the strategy made at the headquarters about manufacturing maritime equipment in China, as remarked by the subsidiary manager of the production unit in China.

It was decided on board level of the group but not taken further down in the organisation [to the subsidiary]. We had to learn from Danish companies that are here in China. They have a much more open strategy. I met [names withheld], and on their side, when they presented their organisation and factory in China, it is written that within two years, all production will take place in China. This was not written anywhere in [our company]. [But we said to ourselves] After some time, maybe this product will have to be produced in China.

The above quotation is related to the knowledge brokerage role in that communicative interactions are made by subsidiary managers to interpret elements of a

(C) The Author(s), 2021. Published by Cambridge University Press on behalf of The International Association for Chinese Management Research 
global business model as the basis for making judgements about the feasibility of a value proposition and legitimising the actions to take in response (Wallnöfer \& Hacklin, 2013). The different working practices between the headquarters and subsidiaries can also result in behavioural tensions due to the lack of trust, as remarked by the subsidiary manager:

It's a little bit of that as well but especially the production manager and the manager for the operation in the headquarters. They have said one thing and then done a totally different thing. This I've seen many times when they've been here. And they have been here quite many times, and everything is like sunshine and 'oh yeah, here we are going to do some businesses. As soon as they go back to Norway, which is changed.

The decision-making is usually centralized within the Norwegian MNEs, which is another source of HQS tensions because the subsidiary manager usually hopes to have more autonomy to implement the global business model in the transforming economy. There is a perception gap arising from differences in the behavior of the subsidiary managers vis-à-vis the headquarters managers, which influences decision-making. Here, the relationship management by subsidiary managers becomes crucial, as stated in the below quotation by the Director of Marketing in China in the interview:

It is, but of course, there is where I should use my politician skills, which I don't have! I am a little bit too open, speak a little bit too open and too straight forward sometimes. When you come up to the level where I am now, you sometimes must be a politician to do some lobbying and things like this. I have something to learn here.

In addition, the interview data indicate that it usually takes a much longer time for senior managers at the headquarters to initiate change in global business models than the subsidiary managers had expected, which led to the tensions. This was typified in relationship management, evidenced in accounts of how the subsidiary manages relationships with the headquarters to facilitate value delivery and value capture (e.g., Dunford et al., 2010). For example, the Director of Engineering in the subsidiary of Shanghai City, East China, made the following comment:

when you settle down, you need to write down what is your product and how to build this product, how to produce it, how to maybe improve this product but anyway you have to write down everything, get all the heads in Norway, squeeze them, get it on the paper and then you can start to produce here because it takes, it will take you a very, very long time, I told him if you are going to do it the Norwegian way. And, actually, here in China, the Chinese government they are not so patient, so after two years you should have positive results.

The above analysis indicates that the factors leading to the behavioural tensions of the MNE include the centralisation of decision-making within the headquarters, lack of trust, and different working practices between the headquarters and subsidiaries in the transforming economy. Subsidiary managers

(C) The Author(s), 2021. Published by Cambridge University Press on behalf of The International Association for Chinese Management Research 
need to make effective relationship management with HQ to solve the behavioural tensions.

\section{Cultural Tensions}

The global business model of the Norwegian maritime MNE emphasizes the close involvement in the whole shipbuilding processes in transforming economies. In practice, the subsidiary manager acts as an important knowledge broker to ensure value co-creation with its stakeholders in transforming economies. To reduce the possibility of perception gaps that can be associated with cultural tension (e.g., Lunnan \& McGaughey, 2019), local teams were set up on-site at the shipyards to ensure efficient project management and communication among the subsidiary, headquarters, shipyards, and ship owners. This is related to communicative interactions used by managers to interpret and act on business models (Wallnöfer \& Hacklin, 2013). This had to do with the fact that the MNE cooperated with local shipyards in transforming economies. Meanwhile, the MNE's shipyard in Norway also played an important role in contributing to its design success and providing the shipyards and its business partners in the transforming economy the opportunities to visit the shipyard and headquarters in Norway to experience the innovative new-generation of vessels that were being designed and constructed. The Manager of Sales and Engineering Unit in China made the following comment in the interview:

In China, we have staff at the shipyards for all vessels under construction, providing sourcing support and feedback on construction, which we forward to the design team in Norway. There is direct communication every single day. So, you can see the bridge, but there is also a filter. A lot of the patent correspondence is handled by us. We filter everything and provide a draft of what type of design, equipment, or solution is needed.

The above quotation about daily communication is related to the knowledge brokerage role of subsidiary managers, seen as important for facilitating the connecting of formal and informal knowledge search and transfer mechanisms across functional and geographical boundaries of MNEs (Patriotta, Castellano, \& Wright, 2013). This helps address cultural tensions in the sense that though the MNE operates a centralized global business model, the interview data shows that one of the Chinese subsidiary managers, who had been educated and worked in both China and Norway, plays an important role in orchestrating the local production networks in China and making effective cross-cultural management and communication by distilling the business information from cross-functional teams in China to the headquarters in Norway.

In addition, the guanxi network, which requires the informal building of trust to underpin effective business relationships, plays an important part in the marketing, sales, and delivery of maritime product-service offerings in China (Bu \& Roy, 2015). For example, the marketing manager of the Norwegian maritime MNE's

(C) The Author(s), 2021. Published by Cambridge University Press on behalf of The International Association for Chinese Management Research 
subsidiary in Shanghai City needs to undertake effective management of the local guanxi network to transfer the tacit knowledge from the headquarters in Norway to the shipyards in China successfully.

Our analysis also reveals that the value creation approach emphasised by HQ managers illustrates how the MNE 'builds a wide range of highly efficient vessels with lasting competitiveness' and 'to secure long-term shareholder return'. However, this comes into conflict with perceptions in China, where products and services are assessed on local prices and costs. This is related to customer sensing (Baden-Fuller \& Haefliger, 2013) role of the subsidiary managers as useful for managing cultural tensions by reacting to situations in which the customer does not display the expected reaction to the headquarters' framing of products or services. A subsidiary marketing manager made the following remarks in the interview:

Our main customers are not Chinese ship owners but build vessels in China. The only thing that seems they care about is the price. The cost of this. If you don't' have a very good cooperation with the shipyard, if you are not friends with them, then you can never get a contract here because of the price, because we have a slightly higher indirect cost than other Chinese companies.

We see the above quotation is related to guanxi influences as subsidiary managers rely on informal friendships alongside formal interactions in building long-term relationships both as part of sensing what customers desire but also to market products and services. Through understanding the perception gap in the framing of products and services, the subsidiary is able to manage cultural tensions and help address the global integration-local responsiveness dilemma (Bartlett \& Ghoshal, 1998) that could have potentially had negative impacts on the MNE's revenue generation potential.

\section{DISGUSSION}

\section{Theoretical Implications}

When MNEs implement their global business models in transforming economies, different types of tensions can arise between the headquarters and subsidiaries, which need to be overcome to ensure that their products, services, and delivery mechanisms can be adapted to the needs of local conditions. In examining how the subsidiaries of one leading Norwegian maritime MNE practise its global business model in China, we have made the following two important theoretical contributions to the study of global business models of MNEs in transforming economies.

First, we propose a theoretical framework for understanding the practice of MNEs' global business models in transforming economies, focusing on the role of subsidiary managers (Figure 2). The framework links the headquarters perspectives of the components of a global business model (left), the tensions between the 
Global Business Model

(HQ Managers)
Global Business Model

(Subsidiary Managers)

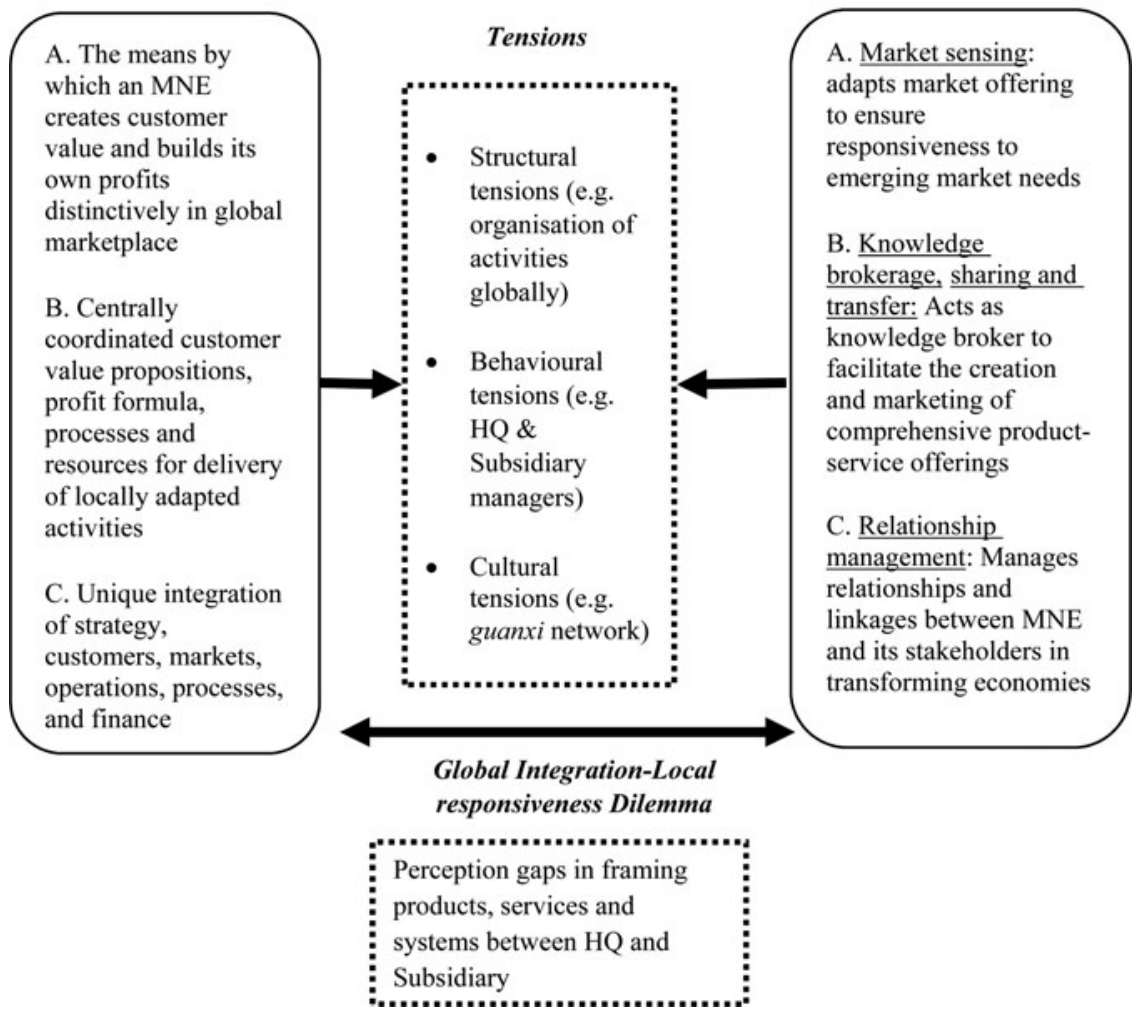

Figure 2. Understanding the practice of MNEs' global business model by subsidiary managers in transforming economies

headquarters in a western MNE context, and the subsidiaries in a transforming economy (middle), and the practices of the subsidiary managers in the transforming economy (right). The two-way arrow at the bottom of Figure 2 is the feedback loop to the headquarters, illustrating the global integration-local responsiveness dilemma (Bartlett \& Ghoshal, 1998). This dilemma is evidenced in the perception gaps between an MNE's headquarters and subsidiaries. The examples of perception gaps in our data include the use of 'politics' or 'making friends' as alternatives to rational decision-making by subsidiary managers, the alternative framing of product-service offering to secure buy-in from local partners in the transforming economy. Such examples illustrate how the practices of subsidiary managers (A, $\mathrm{B}$, and $\mathrm{C}$ in the Subsidiary Managers box) combine with the headquarters perspective on tensions along with the response to the global integration-local responsiveness dilemma. Our findings show clearly that subsidiary managers need to un-pack in the transforming economy what might otherwise seem to be a rational, coherent global business model from the perspective of the headquarters.

The framework shows that subsidiary managers implement the MNEs' global business model through understanding and managing the tensions between the 
headquarters based in a western country and the subsidiaries located in a transforming economy. Evidence of understanding and managing tensions have been uncovered through examining the communicative interactions (Wallnöfer \& Hacklin, 2013) that the subsidiary managers have with key stakeholders within the MNE's global business networks. For this, the subsidiary managers perform three key functions, namely market sensing, knowledge brokerage (sharing and transfer), and relationship management (see A, B, and $\mathrm{G}$ in the right column of Figure 2). Our emergent framework complements the existing literature on global business models of MNEs (e.g., Baden-Fuller \& Haefliger, 2013; Tallman et al., 2018) by addressing how MNEs operating in transforming economies can achieve local responsiveness by ensuring that subsidiary managers understand how to manage the tensions associated with the implementation of global business model.

For instance, by assessing that the clients in transforming economies of Asia and Latin America are price-sensitive and do not place quality as their core orientation, this is a challenge for the headquarters and subsidiary managers, who strive for local responsiveness (Wei et al., 2014). To deal with this global integration-local responsiveness dilemma, the subsidiary managers of the MNE were inspired by the adaptation of the ship design to a more 'cost-effective design' of tangible (ship design) and intangible (value for money) components. Thus, the subsidiary manager deals with global integration and local responsiveness dilemma (Bartlett \& Ghoshal, 1998) by enlisting customers' preferences and securing local buy-in. Chang and Park (2012) explore how Chinese customers have become more demanding with both price and value important consideration in their choices of product and service offerings, a change requiring western MNEs in China to develop strategies that enable them to use market heterogeneity and technological complexity to become competitive. This suggests that the practice of global business models goes beyond, enabling MNEs to 'select technologies and features to be embedded in the product and/or service' (Teece, 2010: 173). The in-depth case study in this article indicates that the subsidiary managers act as high-level knowledge intermediary (Patriotta et al., 2013) in the successful implementation of global business models in transforming economies.

Our second main contribution is that we have uncovered how the management of structural, behavioural, and cultural tensions by subsidiary managers enables MNEs to deal with the global integration-local responsiveness dilemma more effectively in the transforming economy. These tensions are consistent with those faced by MNEs that try to use globally-oriented and locally-focused capabilities simultaneously. For example, behavioural and cultural tensions mainly arise from mistrust between the headquarters and subsidiary managers. Structural tensions can result from managing multiple organizational sub-systems and the inherent organizational contradictions (Fourné et al., 2014; Toth et al., 2018). With respect to managing the tensions, our findings reveal it is important for subsidiary managers to communicate the value proposition to the local stakeholders effectively while aligning to the MNE's global business model requirements. 
According to Baden-Fuller and Haefliger (2013), many MNEs fail commercially in transforming economies because little attention has been given to adapting their global business models to the transforming economies properly. They need help to remedy market-specific challenges by their subsidiaries. To interpret and coordinate actions within an MNE's global production networks (Lunnan \& McGaughey, 2019), subsidiary managers act as knowledge brokers in that they keep sensing the local business environment in transforming economies and contribute to developing the strategic direction and global business model of the MNE. For example, the subsidiary manager is able to try something new or experiment (Dunford et al., 2010) by using alternative interpretations of existing productservice offering to enroll customers and suppliers in the transforming economy into the MNE's international business activities and strategies while keeping close communication with the headquarters.

With respect to knowledge transfer, knowledge sharing, and networking relationships (e.g., Asmussen et al., 2013), our results reveal how the subsidiary managers act as 'bridge' and 'filter' interactions between the headquarters and stakeholders, which helps protect the MNEs' core competencies in transforming economies. As a 'filter', the subsidiary interacts with both internal and external stakeholders in the transforming economy and sends to the headquarters only information that is consistent with the core principles of the MNE's global business model. This role of the subsidiary ensures that customers and suppliers in transforming economies primarily have contact with the subsidiary, and not with the headquarters, enabling the MNEs to protect their internalization advantages. The only exception to this occurred in situations where on-site subsidiary teams at the shipyards have a mandate to secure direct contact between headquarters and local business partners. This is crucial for protecting competencies when operating in transforming economies such as China, where market heterogeneity and technological complexity require broadening and deepening the local knowledge and relationships to enhancing the competitiveness of MNE (Chang \& Park, 2012; Prashantham, Zhou, \& Dhanaraj, 2020). While subsidiary roles can be defined by headquarters, our findings are consistent with the view that certain strategic choices should be available to subsidiaries beyond those provided by headquarters in transforming economies (Birkinshaw et al., 2005; Miozzo \& Yamin, 2012). Therefore, we do not suggest that the practices of global business models by subsidiary managers in transforming economies can be similar to those in developed economies due to their specific institutional environments.

\section{Managerial Implications}

The empirical case study has provided practice lessons that can inform the headquarters-subsidiary interactions and activities for those MNEs that implement global business models in transforming economies. Subsidiary managers need to constantly undertake market sensing activities to adapt market offerings of 
MNEs to meet the needs of the transforming economy. To effectively manage the integration of the transforming economy into MNEs' global production networks and the delivery of value co-creation with the local business partners, subsidiary managers act as knowledge brokers to facilitate the creation and communication of the value proposition to stakeholders, contributing to the successful implementation of the global business model of MNEs in transforming economies.

The business environment in a transforming economy such as China is constantly evolving and has a distinctive governance mechanism, which differs from that in the western developed countries considerably (Lewin, Välikangas, \& Chen, 2017). To succeed in such a business environment, subsidiary managers of western MNEs in the transforming economy must understand and work with structural, behavioural, and cultural tensions along with the global integration-local responsiveness dilemma effectively. They need to be simultaneously cognizant of and engage in those practices which are most fit for the particular type of transforming economy stakeholders. For example, with respect to cultural tensions, the subsidiary managers should make effective cross-cultural management between HQ and transforming economies, understanding that cultural practices in a country such as China can often be judged moral grounds leading to negative influences, which may affect the performance of the subsidiary (Bu \& Roy, 2015). This understanding enables the subsidiary manager to better share and transfer knowledge, which is useful for facilitating the creation and marketing of comprehensive product-service offerings from the headquarters to satisfy the local needs.

\section{Limitations and Future Research Opportunities}

Our study has opened up two possibilities for future research. First, though we uncovered three tensions and link these to three roles for HQ managers in the implementation of business models, our data does not sufficiently allow us to assess whether all three roles are equally important for all tensions or whether some roles are more important in solving some tensions than others. Future quantitative research utilizing multiple case studies of HQS managers can build and strengthen our findings in this area. We believe our data does not sufficiently allow us to determine whether the roles are equally important for all tensions. We have recognised this as a limitation and suggested for future research.

Second, while we adopt the perspective of the MNE in implementing the global business model, the customers' perspective in transforming economies is equally critical and important (Kristensson, Matthing, \& Johansson, 2008). This is relevant because value creation in the practice of the global business model is seen as a mutual co-evolving activity involving an MNE and its business network partners, such as suppliers, customers, and other stakeholders. Our discussion of the relationships among the headquarters, subsidiary, business partners, and clients require further enquiry in relation to the organizational and knowledge 
management challenges under global network architecture. The existing research on global business models of MNEs suggests that such relationships have implications for industry boundaries and industry evolution (Miozzo \& Yamin, 2012; Teece, 2010). Future research in this area can improve our understanding of relationship management in global business models implementation in transforming economies.

\section{GONCLUSION}

In this article, we have developed an empirically grounded theoretical framework for understanding how subsidiary managers of western MNEs manage the structural, behavioural, and cultural tensions between headquarters and subsidiaries along with the global integration- local responsiveness dilemma when implementing global business models in transforming economies. Our findings reveal how the subsidiaries of one leading Norwegian maritime MNE communicated the value of their market offering to convey both tangible and intangible elements and to do so in a way that reflects the strategic objectives of the headquarters and the responsiveness challenges of the host transforming economy.

However, it is not argued in this article that MNEs in the maritime industry are unique in terms of implementing their global business models. The cases of MNEs such as global retail banks (Dunford et al., 2010) or the recorded music industry (Mason \& Spring, 2011) also point to a global business model focus in responding to international competitiveness and local responsiveness. Our focus on the maritime industry complements and extends the existing literature by demonstrating how the practice of global business models by MNEs involves understanding and managing tensions between their headquarters and subsidiaries in transforming economies with special reference to China. More research using multiple case studies can clarify the conditions under which each of the three subsidiary manager roles contributes to solving each of the three tensions in our proposed framework.

Regarding our theoretical contribution around addressing the tensions between headquarters and subsidiaries of MNEs in the transforming economy, the literature mainly deals with the tensions as problems or challenges, but what we have shown is that the tensions can also be a source for innovation and change. Subsidiary managers may be innovative because they keep sensing and seizing local business opportunities while implementing global business models in transforming economies.

\section{NOTES}

We gratefully acknowledge the research funding from the Research Council of Norway, MAROFF programme with Grant Number 199753. This paper has improved greatly under the constructive feedback and guidance by the Special Issue Editors and three anonymous reviewers. We also would like to thank the participants at the MOR paper development workshop held at Vrije Universiteit Amsterdam, Amsterdam, The Netherlands, in July 2019 for their helpful comments and feedback.

(C) The Author(s), 2021. Published by Cambridge University Press on behalf of The International Association for Chinese Management Research 


\section{REFERENGES}

Aguinis, H., \& Solarino, A. 2019. Transparency and replicability in qualitative research: The case of interviews with elite informants. Strategic Management Journal, 40(8): 1291-1315.

Ambos, T. C., Andersson, U., \& Birkinshaw, J. 2010. What are the consequences of initiative-taking in multinational subsidiaries? Journal of International Business Studies, 41(7): 1099-1118.

Amdam, R. P., \& Bjarnar, O. 2015. Globalization and the development of industrial clusters: Comparing two Norwegian clusters 1900-2010. Business History Review, 89(4): 693-716.

Amdam, R. P., Bjarnar, O., \& Wang, J. 2018. The dynamic role of small- and medium-sized multinationals in global production networks: Norwegian maritime firms in the Greater Shanghai Region in China. Asia Pacific Business Reviez, 24(1): 37-82.

Andersson, U., Forsgren, M., \& Holm, U. 2007. Balancing subsidiary influence in the federative MNE: A business network view. Journal of International Business Studies, 38(5): 802-818.

Asakawa, K. 2001. Organizational tension in international R\&D management: The case of Japanese firms. Research Policy, 30(5): 735-757.

Asmussen, G. G., Foss, N. J., \& Pedersen, T. 2013. Knowledge transfer and accommodation effects in multinational corporations: Evidence from European subsidiaries. Journal of Management, 39(6): 1397-1429.

Aspara, J., Lamberg, J-A., Laukia, A., \& Tikkanen, H. 2013. Corporate business model transformation and inter-organizational cognition: The case of Nokia. Long Range Planning, 46(6): 459-474.

Baden-Fuller, G., \& Haefliger, S. 2013. Business models and technological innovation. Long Range Planning, 46(6): 419-426.

Bartlett, G. A., \& Ghoshal, S. 1998. Managing across borders: The transnational solution. Boston, MA: Harvard Business School Press.

Birkinshaw, J., Holm, U., Thilenius, P., \& Arvidsson, N. 2000. Consequences of perception gaps in the headquarters-subsidiary relationship. International Business Review, 9(3): 321-344.

Birkinshaw, J., Hood, N., \& Young, S. 2005. Subsidiary entrepreneurship, internal and external competitive forces, and subsidiary performance. International Business Review, 14(2): 227-248.

Bu, N., \& Roy, J-R. 2015. Guanxi practice and quality: A comparative analysis of Chinese managers' business-to-business and business-to-government ties. Management and Organization Review, 11(2): 263-287.

Chan, G-F., \& Holbert, N. B. 2001. Marketing home and away: Perceptions of managers in headquarters and subsidiaries. Journal of World Business, 36(2): 205-221.

Chang, S., \& Park, S. H. 2012. Winning strategies in China: Competitive dynamics between MNEs and local firms. Long Range Planning, 45(1): 1-15.

Chini, T., Ambos, B., \& Wehle, K. 2005. The headquarters subsidiaries trench: Tracing perception gaps within the multinational corporation. European Management Journal, 23(2): 145-153.

Couper, C. 2019. Institutional bridging for SME high-distance internationalisation to China: A contextualised explanation. Management and Organization Review, 15(2): 307-340.

Dunford, R., Palmer, I., \& Benveniste, J. 2010. Business model replication for early and rapid internationalisation: The ING direct experience. Long Range Planning, 43(5/6): 655-674.

Eisenhardt, K., \& Graebner, M. 2007. Theory building from cases: Opportunities and challenges. Academy of Management Journal, 50(1): 25-32.

Forkmann, S., Ramos, C., Henneberg, S., \& Naudé, P. 2017. Understanding the service infusion process as a business model reconfiguration. Industrial Marketing Management, 60(1): 151-166.

Fourné, S. P., Jansen, J. J., \& Mom, T. J. 2014. Strategic agility in MNEs: Managing tensions to capture opportunities across emerging and established markets. California Management Review, 56(3): 13-28.

Gehman, J., Glaser, V. L., Eisenhardt, K. M., Gioia, D., Langley, A., \& Corley, K. G. 2018. Finding theory-method fit: A comparison of three qualitative approaches to theory building. Journal of Management Inquiry, 27(3): 284-300.

Gioia, D. A., Corley, K. G., \& Hamilton, A. L. 2013. Seeking qualitative rigor in inductive research: Notes on the Gioia methodology. Organizational Research Methods, 16(1): 15-31.

Hambrick, D. 2007. Upper echelons theory: An update. Academy of Management Review, 32(2): 334-343.

Jia, L., You, S., \& Du, Y. 2012. Chinese context and theoretical contributions to management and organization research: A three-decade review. Management and Organization Review, 8(1): 173-209. 
Khanagha, S., Volberda, H. W., \& Oshri, I. 2014. Business model renewal and ambidexterity: Structural alteration and strategy formation process during transition to a Cloud business model. R \& D Management, 44(3): 322-340.

Kostova, T., Marano, V., \& Tallman, S. 2016. Headquarters-subsidiary relationships in MNEs: Fifty years of evolving research. Journal of World Business, 51(1): 176-184.

Kristensson, P., Matthing, J., \& Johansson, N. 2008. Key strategies for the successful involvement of customers in the co-creation of new technology-based services. International Journal of Service Industry Management, 19(4): 474-491.

Kynge, J., Campbell, C., Kazmin A., \& Bokhari, F. 2017. How China rules the waves. [Cited on 15 February 2017]. Available from URL: http://ig.ft.com/sites/china-ports/

Lewin, A. Y., Välikangas, L., \& Chen, J. 2017. Enabling open innovation: Lessons from Haier. International Journal of Innovation Studies, 1(1): 5-19

Lunnan, R., \& McGaughey, L. 2019. Orchestrating international production networks when formal authority shifts. Journal of World Business, 54(5): 1-15.

Lunnan, R., Tomassen, S., Andersson, U., \& Benito, T. 2019. Dealing with headquarters in the multinational corporation: A subsidiary perspective on organizing costs. Journal of Organization Design, 8(12): 2-24.

Luo, Y. 2003. Market-seeking MNEs in an emerging market: How parent-subsidiary links shape overseas success. Joumal of International Business Studies, 34(3): 290-309.

Luo, Y., \& Child, J. 2015. A composition-based view of firm growth. Management and Organization Revieze, 11(3): 379-411.

Martins, L. L., Rindova, V. P., \& Greenbaum, B. E. 2015. Unlocking the hidden value of concepts: A cognitive approach to business model innovation. Strategic Entrepreneurship Journal, 9 (1): 99-117.

Mason, K., \& Spring, M. 2011. The sites and practices of business models. Industrial Marketing Management, 40(6): 1032-1041.

Massa, L., Tucci, C. L., \& Afuah, A. 2017. A critical assessment of business model research. Academy of Management Annals, 11(1): 73-104.

Mihalache, M., \& Mihalache, O. R. 2020. What is offshoring management capability and how do organizations develop it? A study of Dutch IT service providers. Management International Revieze, 60(1): 37-67.

Miozzo, M., \& Yamin, M. 2012. Institutional and sectoral determinants of headquarters-subsidiary relationships: A study of UK service multinationals in China, Korea, Brazil and Argentina. Long Range Planning, 45(1): 16-40.

Ngoasong, M. 2010. The impact of global health partnerships on access to medication in Cameroon: Theory, models and policy practices. PhD Thesis, University of Nottingham, UK.

Patriotta, G., Castellano, A., \& Wright, M. 2013. Coordinating knowledge transfer: Global managers as higher-level intermediaries. Joumal of World Business, 48(4): 515-526.

Plakoyiannaki, E., Wei, T., \& Prashantham, S. 2019. Rethinking qualitative scholarship in emerging markets: Researching, theorizing, and reporting. Management and Organization Revieze, 15(2): 217-234.

Prashantham, S., Zhou, A. J., \& Dhanaraj, C. 2020. Depth vs. breadth: Network strategy in emerging markets. Management and Organization Revieze, 16(2): 1-32.

Rodrigues, C. 1995. Headquarters-foreign subsidiary control relationships: Three conceptual frameworks. Empozerment in Organizations, 3(3): 25-34.

Tallman, S., Luo Y., \& Buckley, P. J. 2018. Business models in global competition. Global Strategy Journal, 8(4): 517-535.

Tasoluk, B., Yaprak, A., \& Calantone, R. J. 2006. Conflict and collaboration in headquarterssubsidiary relationships: An agency theory perspective on product rollouts in an emerging market. International Joumal of Conflict Management, 17(4): 332-351.

Teece, D. J. 2010. Business models, business strategy and innovation. Long Range Planning, 43(2/3): 172-194.

Teece, D. J., Pisano, G., \& Shuen, A. 1997. Dynamic capabilities and strategic management. Strategic Management Journal, 18(7): 509-533.

Tippmann, E., Scott, P., \& Mangematin, V. 2014. Subsidiary managers' knowledge mobilizations: Unpacking emergent knowledge flows. Journal of World Business, 49 (3): 431-444.

Toth, Z., Peters, L. D., Pressey, A. D., \& Johnston, W.J. 2018. Tension in a value co-creation context: A network case study. Industrial Marketing Management, 70: $34-45$. 
Volberda, H. W., Mihalache, R. O., Fey, C. F., \& Lewin, A. Y. 2017. Management and Organization Review special issue: Business model innovation in transforming economies. Management and Organization Revieze, 13(2): 459-462.

Volberda, H. W., Van den Bosch, F. A. J., \& Heij, K. 2017. Re-inventing business models: How firms cope with dismuption. Oxford: Oxford University Press.

Wallnöfer, M., \& Hacklin, F. 2013. The business model in entrepreneurial marketing: A communication perspective on business angels' opportunity interpretation. Industrial Marketing Management, 42(5): 755-764.

Wei, Y., Samiee, S., \& Lee, R. 2014. The influence of organic organizational cultures, market responsiveness, and product strategy on firm performance in an emerging market. Journal of the Academy of Marketing Science, 42(1): 49-70.

Zhang, Y., Dolan, S., Lingham, T., \& Altman, Y. 2009. International strategic human resource management: A comparative case analysis of Spanish firms in China. Management International Reviez, 5(2): 195-222.

Michael Zisuh Ngoasong (michael.ngoasong@open.ac.uk) is a Senior Lecturer in Management at Open University Business School in the United Kingdom and Senior Research Associate at the University of Johannesburg in South Africa. He completed his $\mathrm{PhD}$ at the University of Nottingham in the United Kingdom and taught at Coventry University London prior to joining The Open University. Dr. Ngoasong specializes in the practice of business models and entrepreneurship development in resource-constrained contexts.

Jinmin Wang (jinmin.wang@nottingham.ac.uk) is an Assistant Professor in International Business and Strategy at Nottingham University Business School in the United Kingdom. His research focuses on international strategy of MNEs, SME internationalisation, business model innovation, institutional change, and the development of industrial clusters in transforming economies.

Rolv Petter Amdam (rolv.p.amdam@bi.no) is Professor of Business History at BI Norwegian Business School, Norway. He has been Dean of BI's executive programs, which include the BI - Fudan MBA program. He has published in journals such as Journal of World Business, Business History Review, Business History, and Management $\mathcal{E}$ Organizational History. Currently, he works on a project on the global expansion of executive education.

Ove Bjarnar (Ove.Bjarnar@himolde.no) is Professor of History at Molde University College - Specialized University in Logistics, Norway. In recent years, he has co-authored articles in leading academic journals on the evolution of industrial clusters with a special focus on globalization and changing prerequisites for regional flow of knowledge. He has been Visiting Fellow at BI Norwegian Business School, Norway, and the University of Reading, Henley Business School, the United Kingdom.

Manuscript received: April 16, 2018

Final version accepted: July 13, 2020 (number of revisions - 3) 